differing communities to evolve on the basis of their own particular traditions. In answer to questions, Lord Harlech spoke of the desirability of fostering the undoubted democratic elements in the traditional government of such African peoples as the Basuto.

\title{
Gold Coast Constitutional Changes
}

THE Secretary of State for the Colonies announced in the House of Commons in October 1944 that the recommendations for constitutional reform, submitted by the Governor of the Gold Coast after consultation with representative African opinion, had received approval in principle. It is proposed to grant an unofficial majority on the Legislative Council, and to include representatives of Ashanti as well as of the Colony. The Council would then consist of the Governor, as President without vote; six official members; nine provincial members for the Colony, elected by the joint Provincial Council; four members for Ashanti, elected by the Ashanti Confederacy Council; five municipal members elected by ballot; six nominated members appointed by the Governor. The Governor would also have power to appoint extraordinary members without votes.

\section{Gold Coast Social Services Department}

IN June 1944 the Secretary of State for the Colonies stated that a Social Services Department had been established on the Gold Coast in order to ensure co-ordination of the work of the different Government departments and other agencies concerned in Social Welfare. A senior Welfare Officer has been appointed and seven specially selected men from the Gold Coast are being trained in the United Kingdom preparatory to being posted. Their work will be concerned with probation, junior delinquency, youth activities, rehousing schemes, and other welfare problems.

\section{African Sociology}

THE establishment of an Institute at Makerere for the study and teaching of African Sociology and languages was among the subjects of discussion during the recent visit to Uganda and Kenya of Dr. Audrey Richards of the Colonial Research Committee. The need for research workers in African Sociology, both in rural and urban areas, and the general questions of social welfare services and mass education among Africans after the war were also discussed.

\section{Co-operative Societies}

THE value of co-operative societies in rural communities was stressed by Sir Atthur Richards, G.C.M.G., Governor of Nigeria, in a speech at the opening of the Centenary Co-operative Conference at Lagos. The Governor appealed to the young African farmer to learn to read and write through his co-operative society, and he urged doctors, lawyers, teachers, and journalists to place their experience at the service of the co-operative movement.

At Ejura, in the Gold Coast, the farmers of the district decided unanimously that cooperation in farming would be of great advantage to them. One hundred and sixty farmers have formed a society which is to be affiliated to the Co-operative Society at Kumasi.

\section{Lowain University: Training Courses for Colonial Administrators}

A cocrse of lectures has been started at Louvain Catholic University, designed for the training of Colonial magistrates and administrators. To qualify for a licenciate in political and colonial sciences four years' study will be required, but only two years' work will be necessary if the student is already a Doctor of Laws or has attended the lectures of the School of Political and Social Sciences for two years. 